\title{
SISTEM INFORMASI PROFIL DAERAH KABUPATEN SIDOARJO BERBASIS WEB
}

\author{
Hani Nurhayati \\ Teknik Informatika UIN Maulana Malik Ibrahim Malang
}

\begin{abstract}
Abstrak - Sistem Informasi Profil Daerah (SIPD) adalah suatu sistem informasi yang menyajikan basis data dalam bentuk 8 kelompok meliputi ; data umum,sosial budaya, sumberdaya alam, infrastruktur, industri perdagangan, keuangan, koperasi, usaha kecil, dan investasi, ekonomi, politik, hukum dan keamanan. Kelompok data tersebut diharapkan mampu menjadi pusat komunikasi informasi berbagai pihak baik pemerintah, masyarakat dan investor dan dapat menggambarkan kondisi fisik Kabupaten Sidoarjo secara lebih rinci dan akurat, sehingga dapat dimanfaatkan untuk bahan pengambil keputusan baik oleh pemerintah daerah maupun pusat. Pengembangan aplikasi SIPD berbasis Web mempunyai peranan SIPD Kabupaten merupakan subsistem dari Sistem Provinsi, dan Provinsi Merupakan Susbsistem dari Sistem Pusat (Nasional) ; Kabupaten memberikan laporan keterisian database secara rutin (Triwulan, Semesteran dan Tahunan) kepada Provinsi; Kabupaten membangun SIPD sesuai dengan format database yang dikembangkan di Provinsi dan Pusat Pengelolaan data dan informasi dalam suatu sistem informasi manejemen yang didukung teknologi komunikasi dan informasi diharapkan mampu menganalisa dan menampilakan data dan informasi sesuai dengan kebutuhan pengguna atau pemakai.
\end{abstract}

Kata kunci : Sistem Informasi Profil Daerah (SIPD), Sistem Informasi Manajemen (SIM), Web.

\section{PENDAHULUAN}

Semakin maju suatu negara / daerah, semakin tinggi tuntutan terhadap penyediaan data dan informasi yang akurat. Berdasarkan asumsi tersebut, urgensi penyediaan data menjadi sejalan dengan akselerasi pembangunan yang dilaksanakan suatu daerah. Disamping

untuk keperluan perencanaan, data diperlukan untuk bahan dalam proses pembuatan keputusan yang efektif.

Penyediaan data dan informasi oleh pemerintah, merupakan upaya yang ditempuh untuk mewujudkan akuntabilitas publik serta membangun citra pemerintah yang bersih, berwibawa, dan bertanggungjawab. Manajemen data dan informasi dalam suatu pengelolahan basis data yang terintegrasi akan memudahkan berbagai pihak mengetahui potensi dan permasalahan di suatu daerah.
Mengacu pada Surat Edaran Menteri Dalam Negeri Nomor 120.04/1791/Bangda, tanggal 31 Oktober 2003 perihal Rencana Kegiatan Program Pengembangan Sistem Informasi Profil Daerah dan Laporan Kinerja Penyelenggaraan Pemerintah Daerah, dimana Pemerintah Kabupaten/Kota di Indonesia diintruksikan untuk melaksanakan kegiatan dalam rangka penyediaan data dan informasi melalui penyusunan basis data ke dalam "delapan kelompok data" berbasis pada teknologi informasi yang terintegrasi.

Sistem Informasi Profil Daerah (SIPD) adalah suatu sistem informasi yang menyajikan basis data dalam bentuk delapan kelompok data meliputi :

(1). Data Umum (2). Sosial Budaya (3). Sumberdaya Alam (4). Infrastruktur (5). Industri, Perdagangan, Keuangan, Koperasi, Usaha Kecil dan Investasi (6). 
Ekonomi dan Keuangan (7). Politik, Hukum dan Keamanan (8). Insidental

Maksud pengembangan manajemen data kedalam Sistem Informasi Profil Daerah (SIPD) antara lain adalah untuk meyediakan dan memenuhi kebutuhan akan data dan informasi guna

meningkatkan kapasitas daerah, khususnya sebagai bahan untuk menyusun perencanaan pembangunan di tingkat Daerah sampai Pusat.

Tujuan dari kegiatan pengembangan Sistem Informasi Profil Daerah (SIPD) berbasis web adalah :

(1). Untuk meningkatkan kesadaran dan komitmen pemerintah daerah akan pentingnya data dan informasi

(2). menyediakan data secara tepat, cepat, dan akurat serta infrastruktur bagi pengambil keputusan di tingkat Daerah dan Pusat

(3). meningkatkan kelancaran komunikasi data dan informasi antar Daerah ( antar Kabupaten / Kota dengan Propinsi dan antar Daerah dengan Pusat

(4). Meningkatkan kinerja penyelenggaraan pemerintah

\section{KONDISI LOKAL DAERAH}

\subsection{Data Umum}

\section{(1). Letak Geografis}

Kabupaten Sidoarjo adalah Kabupaten yang dihimpit dua sungai, sehingga terkenal dengan Kota Delta. Kabupaten Sidoarjo terletak antara 112,50 - 112,90 Bujur Timur dan 7,30 - 7,50 Lintang Selatan. Batas wilayah :

- Sebelah Utara berbatasan dengan Kota Surabaya dan Kabupaten Gresik

- Sebelah timur berbatasan dengan laut yang dinamakan Selat Madura

- Sebelah Selatan berbatasan dengan Kabupaten Pasuruan

- Sebelah Barat berbatasan dengan Kabupaten Mojokerto

(2). Luas Wilayah

Luas wilayah Kabupaten Sidoarjo 71.424,25 Ha, 40,81 \% terletak diketinggian $3-10 \mathrm{~m}$ yang berada dibagian tengah dan berair tawar, 29,99\% berketinggian $0-3$ meter berada disebelah Timur dan merupakan daerah pantai dan pertambakan, $29,20 \quad \%$ terletak diketinggian 10 -25 meter berada dibagian barat.

\section{(3). Topografi}

Kabupaten Sidoarjo merupakan suatu wilayah yang mempunyai beberapa beberapa lapisan batuan, untuk batuan Alluvium seluas 686,89 tersebar di semua kecamatan yang ada di Sidoarjo, tapi untuk Lapisan batuan Plistosen Fasien Sedimen hanya terdapat di 6 kecamatan antara lain Kecamatan Sidoarjo 0,4 Km, Buduran 14,69 Km, Taman 4,48 Km, Waru 3,84 $\mathrm{Km}$, Gedangan 0,38 Km, dan Sedati seluas 3,55 Km. Sedangkan lapisan tanah untuk Alluvial kelabu merata di 18 Kecamatan seluas 470,18 Km, Lapisan tanah jenis As. Alluvial Klb dan coklat kekuningan hanya di 4 kecamatan krembung, Balongbendo, Tarik dan Prambon masing - masing 4,54 $\mathrm{km}, 27,95 \mathrm{Km}, 9,87 \mathrm{Km}$, dan 7,33 Km. Lapisan tanah Alluvial Hidromorf seluas 213,61 Km menyebar di 8 Kecamatan Sidoarjo, Buduran, Candi, Porong, Tanggulangin, Jabon, Waru, dan Sedati, adapun lapisan tanah kelabu Tua seluas $8,71 \mathrm{Km}$ di 2 kecamata buduran dan Gedangan Kondisi air ada dua jenis rasa air di Kabupaten Sidoarjo yaitu air asin dan tawar, ada 8 Kecamatan yang sebagian wilayah rasa airnya asin seluas $163,13 \mathrm{Km}$ dan 10 kecamatan murni air tawar.

(4). Iklim

Kabupaten Sidoarjo berada disekitar garis katulistiwa, maka seperti di Kabupaten/Kota lain di Jawa Timur, wilayah ini mempunyai perubahan musim sebanyak 2 kali setiap musimnya, yaitu musim kemarau dan musim penghujan. Musim Penghujan berkisar di bulan Oktober sampai dengan Bulan April dan di bulan selebihnya yaitu bulan Mei sampai september adalah musim kemarau. Adapun Lokasi penangkar Hujan menyebar di 17 Kecamatan kecuali di Kecamatan 
Tulangan tidak ada lokasi penangkar hujan. Curah Hujan di Kabupaten Sidoarjo yang cukup tinggi terjadi di bulan Februari 2007 dan hari hujan terbanyak terdapat di bulan Februari 2007.

\subsection{Bidang Pemerintahan}

(1). Pemerintahan Daerah

Organisasi Perangkat Daerah di Kabupaten sidoarjo terdiri dari:

a. Sekretariat Daerah dan Sekretariat Dewan

b. Dinas - Dinas ( 15 Dinas )

1). Dinas Bina Marga

2). Dinas Cipta Karya dan

Permukiman

3). Dinas Kebersihan dan Pertamanan

4). Dinas Kelautan dan Perikanan

5). Dinas Kependudukan dan Pencatatan Sipil

6). Dinas Kesehatan

7). Dinas Koperasi, UKM, Perindag dan ESDM

8). Dinas Pasar

9). Dinas Pemuda, Olahraga, Kebudayaan dan Pariwisata

10). Dinas Pendapatan, Pengelolaan Keuangan dan Aset
11). Dinas Pendidikan
12). Dinas Pengairan
13). Dinas Perhubungan
14). Dinas Pertanian, Perkebunan dan Peternakan

15). Dinas Sosial dan Tenaga Kerja

c. Lembaga Teknis

1). Badan ( 7 Badan ), terdiri dari :

a). Badan Kepegawaian Daerah

b). Badan Kesatuan Bangsa, Politik dan

Perlindungan Masyarakat

c). Badan Ketahanan Pangan dan Penyuluhan

d). Badan Lingkungan Hidup

e). Badan Pelayanan Perijinan Terpadu

f). Badan Pemberdayaan Masyarakat, Perempuan dan Keluarga Berencana

g). Badan Perencanaan Pembangunan Daerah

2). Rumah Sakit Umum Daerah (RSUD)
3). Kantor Perpustakaan dan Arsip

4). Satuan Polisi Pamong Praja

5). Inspektorat Kabupaten Sidoarjo

6). Kecamatan ( 18 Kecamatan ) terdiri dari :Tarik, Prambom, Krembung, Porong, Jabon, Tanggulangin, Candi, Tulangan, Wonoayu, Sukodono, Sidoarjo, buduran, Sedati, Waru,Gedangan, Taman, Krian, Balongbenda

(2). Aparat Pemerintahan Daerah

Untuk pelaksanaan Penyelenggaraan Pemerintahan dan pelayanan masyarakat, hingga bulan Desember 2007 Kondisi SDM atau PNS di lingkungan Pemerintahan Kabupaten Sidoarjo terdapat 12.291 PNS yang terdiri dari 5.819 laki laki dan 6.472 perempuan dengan latar belakang pendidikan bervariasi dari tingkat SD sampai S2 baik lulusan dalam negeri maupun luar negeri dengan gambaran sebagai berikut : S2 312 orang, S1 5.157 orang, Diploma/Akademi 2.843 orang, SLTA 3.361 orang SLTP 330 orang, SD 288 orang

\section{METODOLOGI PENGEMBANGAN SIPD}

Penyusunan kerangka konsep pembuatan Sistem Informasi Profil Daerah (SIPD) Kabupaten Sidoarjo di dasarkan kepada alur metodologi pembangunan jaringan sistem informasi yang telah disesuaikan dengan tujuan dan sasaran yang telah ditetapkan sebelumnya.

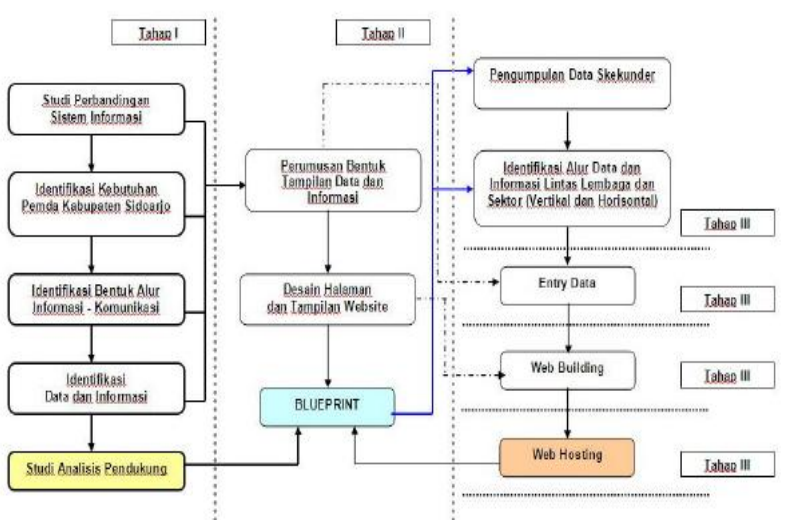

Gambar 1. Alur Metodologi SIPD berbasis WEB 
Pada dasarnya informasi yang terdapat dalam pengembangan aplikasi SIPD berbasis Web mempunyai peranan sebagai berikut :

SIPD Kabupaten merupakan subsistem dari Sistem Provinsi, dan Provinsi Merupakan Susbsistem dari Sistem Pusat (Nasional)

Kabupaten memberikan laporan keterisian database secara rutin (Triwulan, Semesteran dan Tahunan) kepada Provinsi;

Kabupaten membangun SIPD sesuai dengan format database yang dikembangkan di Provinsi dan Pusat

Adapun data atau kelompok data yang harus terpenuhi secara data tabular dan data spatial/Peta, adalah sebagai berikut :

a). Data Spatial/Peta

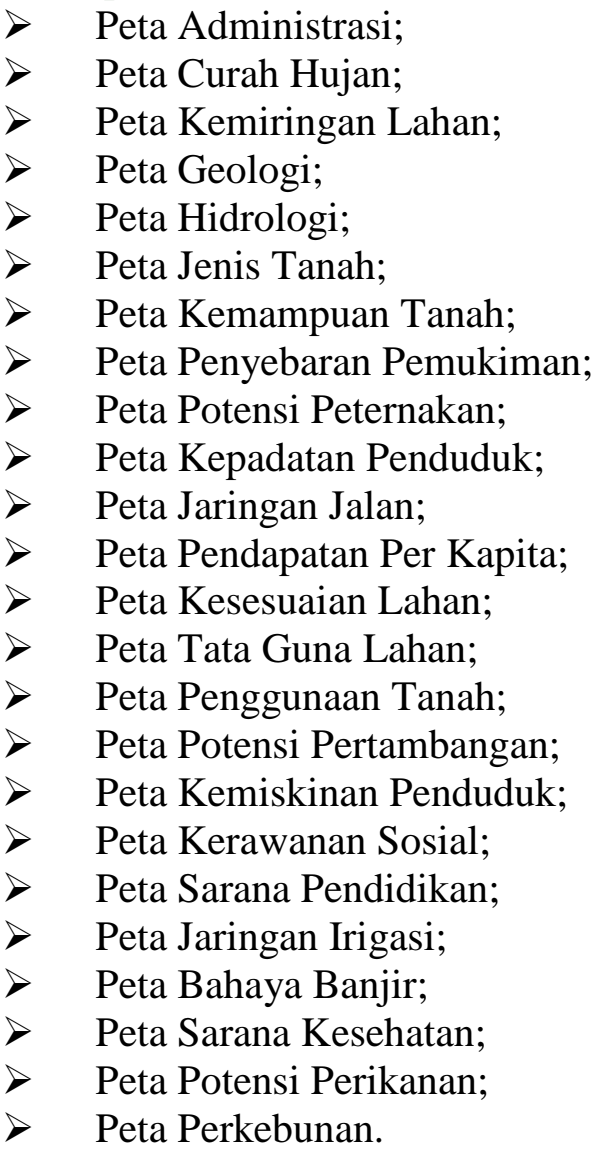

b). Data Tabular

\section{HASIL DAN PEMBAHASAN}

Tampilan pertama dari SIPD berbasis web adalah sebagai berikut :

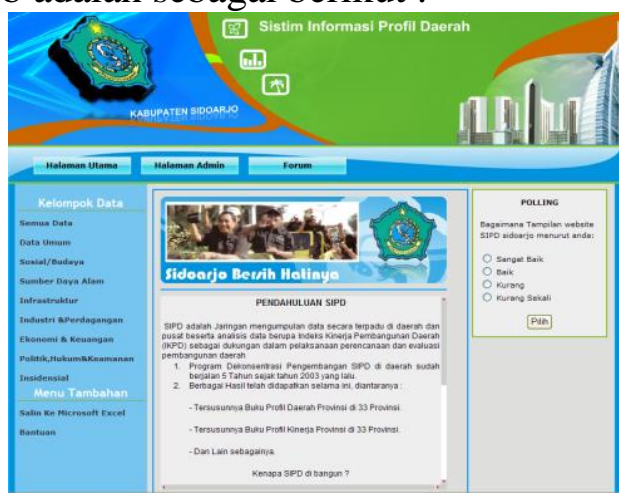

Gambar 2. Halaman pertama

Pada halaman pertama terdapat fitur fitur sebagai berikut :

1. Fitur Link utama:

- Halaman Utama

- Halaman Admin

- Forum

2. Fitur Kelompok Data:

- Semua Data

- Data Umum

- Sosial / budaya

- Sumber daya alam

- Infrastruktur

- Industri dan perdaganagan

- Ekonomi dan keuangan

- Politik, hukum dan keuangan

- Insidensial

3. Fitur Menu Tambahan:

- Salin ke Microsoft excel

- Bantuan

4. Fitur Berita

5. Fitur Polling

Fitur link utama terdapat : halaman utama, halaman admin, forum. Halaman utama merupakan halaman depan atau home dari halaman pengunjung SIPD. Halaman admin ditujukan bagi admin SIPD untuk mengubah atau mengupdate data SIPD. Halaman forum merupakan media komunikasi bagi seluruh admin SIPD. Kelompok data adalah kategori kategori data dari jenis data umum yang di kelompokkan. Sehingga apabila mengakses salah satu kelompok data, 
maka anda akan di arahkan ke halaman berikutnya untuk memilih jenis data yang anda inginkan. Link Semua Data akan menampilkan semua pilihan jenis data.

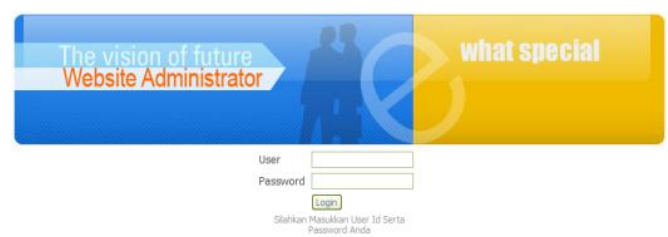

Gambar 3. Halaman admin

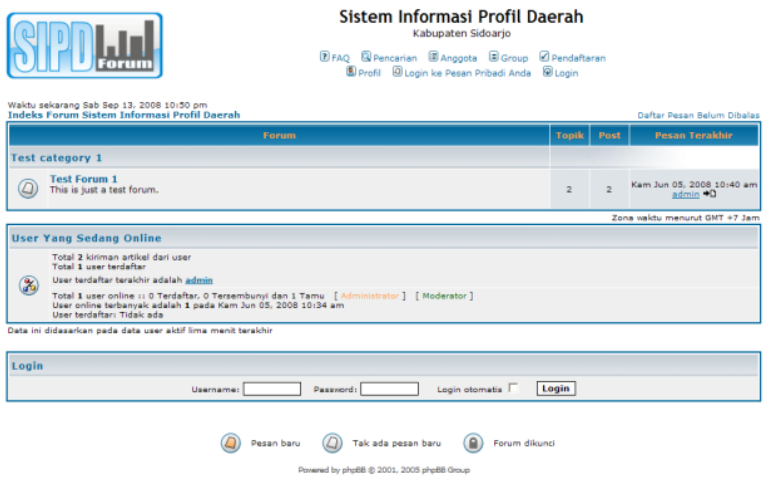

Gambar 4. Halaman forum

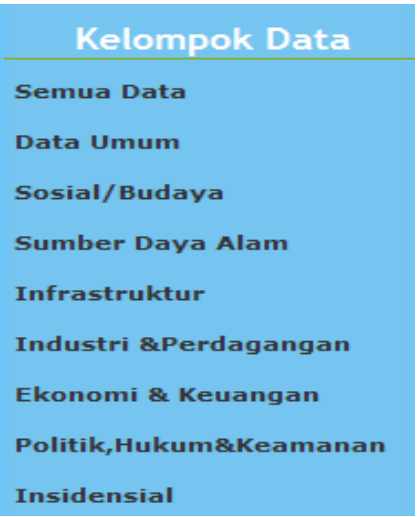

Gambar 5. Link kelompok data

Dari link kelompok data bila dipilih datanya maka akan menampilkan jenis data dan tahun yang diharapkan.

\section{KESIMPULAN}

Pembangunan daerah pada hakekatnya merupakan kegiatan yang dilaksanakan dalam suatu lokasi ( ruang ) tertentu, untuk meningkatkan kesejahteraan masyarakat. Pengembangan aplikasi Sistem Informasi Profil Daerah berbasis web dimaksudkan untuk menyediakan data dan informasi dalam rangka meningkatkan kapasitas daerah bagi perencanaan, pelaksanaan, dan pengendalian pembangunan.

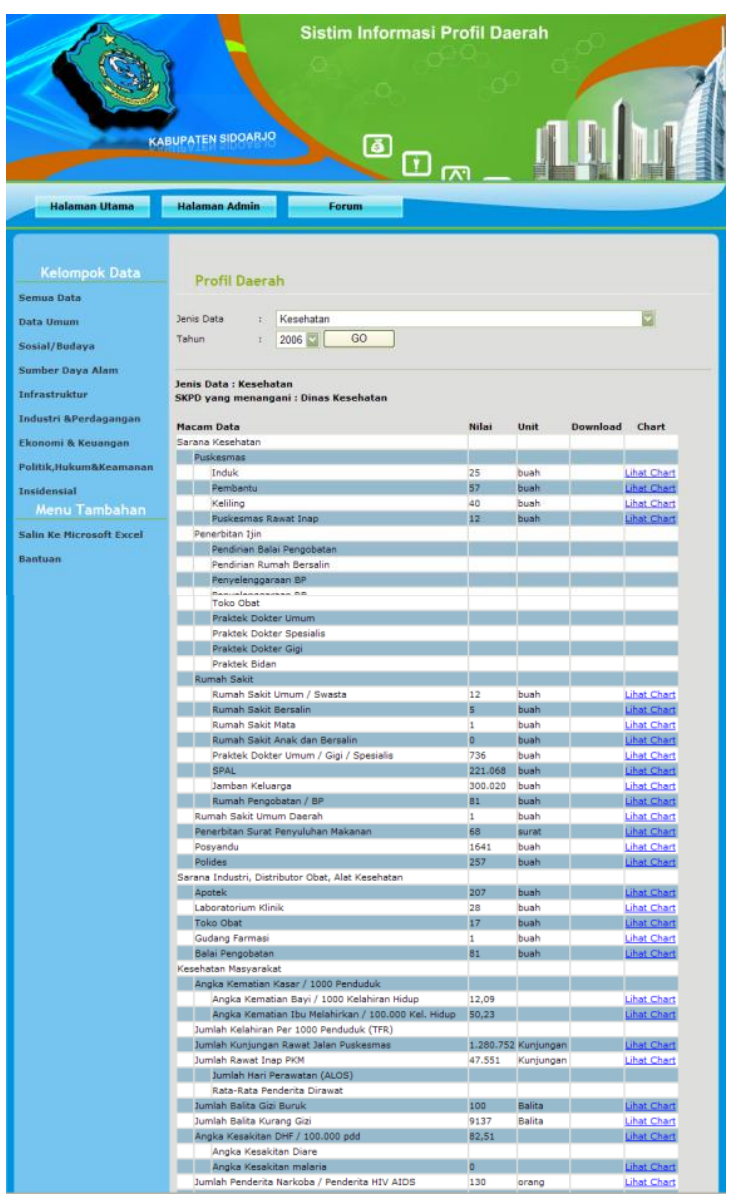

Gambar 6. Halaman data SIPD

Pengembangan Sistim Informasi Profil Daerah ( SIPD ) yang berupa database ke dalam 8 ( Delapan ) kelompok data merupakan upaya Pemerintah Daerah dalam rangka meningkatkan peran data dan informasi yang bersumber dari seluruh Satuan Kerja Perangkat Daerah ( SKPD ) di Kabupaten Sidoarjo bagi tahap proses perencanaan pembangunan. Data tersebut diharapkan mampu menjadi pusat komunikasi informasi berbagai pihak baik pemerintah, masyarakat dan investor dan dapat menggambarkan kondisi fisik Kabupaten Sidoarjo secara lebih rinci dan akurat, sehingga dapat dimanfaatkan untuk bahan pengambil keputusan baik oleh pemerintah daerah maupun pusat. 
Melalui upaya pemanfaatan dan keterpaduan data dan informasi perencanaan, pengendalian dan pembangunan daerah diharapkan pengelolaan data dan informasi bagi perencanaan, pelaksanaan dan pengendalian pembangunan daerah dapat lebih meningkat. Hal ini pada akhirnya akan semakin meningkatkan pula peran Bappeda sebagai lembaga perencana di Daerah dalam memenuhi terciptanya perencanaan pembangunan daerah yang benar - benar sesuai dengan kebutuhan pembangunan daerah.

Pengelolaan data dan informasi dalam suatu sistem manejemen informasi yang didukung teknologi komunikasi dan informasi diharapkan mampu menganalisa dan menampilakan data dan informasi sesuai dengan kebutuhan pengguna atau pemakai.

\section{DAFTAR PUSTAKA}

Anonymous, 2004, Sidoarjo dalam Angka, Sidoarjo

Jogianto, HM, 1991, Pengantar Sistem Informasi Manajemen, Andi Publiser, Yogyakarta.

Nugroho, Andi, 2005, Analisis dan Perancangan Sistem Informasi dengan Metodologi berorientasi Objek, Informatika, Bandung

O'brien, James A, Pengantar Sistem Informasi, MC Graw Hill

Williams, Sawyer, 2007, Using Information Technology edisi 7, Andi Publisher, Bandung 